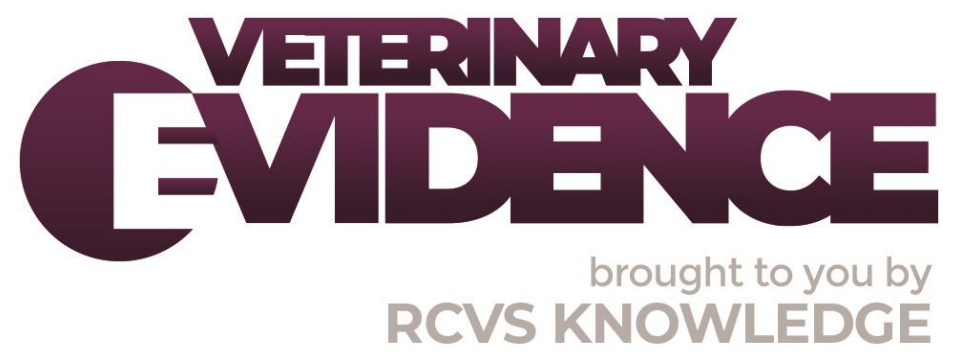

\title{
A scoping review of the current literature exploring the nature of the horse-human relationship
}

\section{H.G.R. Clough BVetSci ${ }^{1}$}

J.H. Burford MA, VetMB, PhD, CertVA, CertES, SFHEA, FRCVS ${ }^{1}$

A.L. Roshier BSc (Hons), PhD, PGCHE, PgCert, MA (Higher Education), MSc (Behaviour Counselling), SFHEA ${ }^{1}$

G.C.W. England BVetMed, PhD, DVetMed, DVR, DVRep, DipECAR, DipACT, PFHEA, FRCVS ${ }^{1}$

S.L. Freeman BVetMed, PhD, CertVA, CertVR, CertES, DipECVS, FHEA, FRCVS ${ }^{1^{*}}$

\footnotetext{
${ }^{1}$ School of Veterinary Medicine and Science, University of Nottingham, College Road, Sutton Bonington, Leicestershire, LE125RD

*Corresponding Author (Sarah.Freeman@nottingham.ac.uk)
}

ISSN: 2396-9776

Published: 20 Nov 2019

in: Vol 4, Issue 4

DOI: $10.18849 / V E . V 414.240$

Reviewed by: Zofia Lisowski (BVSc, PhD, AFHEA, MRCVS), Suzanne Rogers (BSc(Hons) CHBC) and Jo Ireland (BVMS, PhD Cert, AVP(EM), FHEA, MRCVS) 
Objective: To perform a scoping review of the current evidence on the horse-human relationship.

Background: The horse-human relationship has a significant impact on how horse owners care for and make decisions for their horse.

Evidentiary value: Identification of consensus and gaps in current evidence.

Methods: A literature search was performed in CAB Abstracts and Medline using search terms relating to the nature of the horse-human relationship in horses used for pleasure riding. Publications were reviewed against inclusion and exclusion criteria. Original qualitative or observational research studies relating to the relationship between a horse and owner were analysed. Data were extracted on study method and population characteristics.

Results: There were 4,481 studies identified; 27 studies were included in the final data extraction. The studies covered 11 different areas, the most frequent were effect of humans on equine behaviour (5/27), equine training methods and behaviour (4/27) and horses within sport and leisure (4/27). A range of methodologies were used, with the most frequent being thematic analysis (6/27 studies), use of an instrument, tool or scale (3/27) and behavioural scoring (4/27). The majority of studies considered the human's perspective (20/27), six considered the horse perspective and one considered both the horse and human perspective. No studies investigated the same or similar aims or objectives.

Conclusion: The current evidence on the horse-human relationship is diverse and heterogenous, which limits the strength of evidence for any particular area.

Application: Future research should focus on developing reliable and repeatable tools to assess owner motivations and horse-human relationship, to develop a body of evidence.

\section{INTRODUCTION}

From its first domestication over 6,000 years ago, the horse - Equus ferus caballus - has evolved from its primary role as working animal into additional roles as much-loved and reliable companions (Endenburg et al., 1999). The evolution of their use has in turn influenced not only the way we interact with horses today, but also the relationships that are formed between horses and humans (Hausberger et al., 2008). Consequently, it 
is important to gain an understanding of horse-human relationships in today's environment, and how these relationships influence decisions made at key stages within a horse's life.

There are currently around 100 million working equids (horses, donkeys and mules) across the world, predominantly located in poorer or developing countries, where they have a major role in rural economies and the lives of the families and communities that depend on them (World Horse Welfare, 2019). In the UK, the role of the horse is, however, very different. A recent survey carried out by The British Equestrian Trade Association (2019) found that there are around 847,000 horses, and 374,000 horse-owning households in Britain. It has also been reported that $96 \%$ of UK horse owners ride for pleasure and $53 \%$ of these have horses whose main role is for leisure riding and hacking, which represents a major change from a utility-based role, to a companion-based role important in sport and leisure (Dashper, 2014).

A review carried out by Hausberger et al. (2008) explored the various areas of the horse-human relationship which included tools to assess horses' relation to humans, exploration of the bond between a foal and a human, and matching of the horse and rider. This is only a single review and there are no comprehensive peerreviewed studies of the topic. Performing a scoping review to describe the current research available on the horse-human relationship may be beneficial prior to performing systematic reviews. It would enable us to identify and categorise which aspects of the horse-human relationship have previously been explored, and identify where there are existing bodies of evidence or current gaps in knowledge and research. For this study, the definition of 'relationship' described by Hinde (1979) was used: 'the emerging bond from a series of interactions: partners have, on the basis of the past experiences, and expectations on the other individual's responses'.

A scoping review is similar to a systematic review and follows many of the methodological steps. The review type provides a preliminary evaluation of the size and scope of available literature in order to gauge the nature and extent of research evidence (Grant and Booth, 2009). Arksey and O'Malley (2005) described the motivations as to why a scoping review may be performed which included: to investigate the range, extent and type of research activity; to determine the value of performing a full systematic review; to summarise and distribute findings or to identify gaps in the existing literature.

The aim of this scoping review is to investigate and categorise the current published literature regarding the nature of the horse-human relationship in horses used for pleasure riding.

\section{METHODS \& MATERIALS}

\section{Protocol and registration}

This review has not been registered to an existing protocol. This scoping review was conducted using the methodological framework presented by Arksey and O'Malley (2005) and the results are presented using the PRISMA extension for scoping reviews (Tricco et al., 2018).

This project was reviewed and approved by the Ethics Committee, School of Veterinary Medicine and Science, University of Nottingham. 


\section{Eligibility criteria}

To be eligible for the review, papers needed to investigate the relationship, bond or interactions between horse and human for horses used for pleasure. Papers were included if they reported on original research studies, and the full text of the paper was available and published in English. The study focused on the literature around pleasure horses, and therefore studies on animal-assisted therapy, working equids, and horses used for agricultural purposes were excluded (Table 1).

\begin{tabular}{|l|l|}
\hline Inclusion & Exclusion \\
\hline Full text available & Non-English publications \\
\hline Original research & Single cases/essays \\
\hline $\begin{array}{l}\text { Qualitative or observational studies with } \\
\text { methodology capturing a two-way relationship } \\
\text { between horse and human }\end{array}$ & Reviews \\
\hline & $\begin{array}{l}\text { Studies of use of equids for animal-assisted } \\
\text { therapy }\end{array}$ \\
\hline & $\begin{array}{l}\text { Studies of working equids in developing } \\
\text { countries }\end{array}$ \\
\hline & $\begin{array}{l}\text { Studies of equids for agricultural use } \\
\text { (3) }\end{array}$ \\
\hline & $\begin{array}{l}\text { Experimental/quasi-experimental studies which } \\
\text { did not investigate the horse-owner relationship } \\
\text { using an owner/carer in the study design }\end{array}$ \\
\hline
\end{tabular}

Table 1: Inclusion and exclusion criteria used to perform a scoping review of current publications exploring the horse-human relationship.

For the purposes of this study, the following definitions were used for the exclusion criteria:

${ }^{1}$ Studies of use of equids for animal-assisted therapy: defined as a study, or person or people having intermittent access to an animal with the aim of improving specific physical, mental or social functioning. ${ }^{2}$ Studies of working equids in developing countries: defined as studies of working equids in any countries listed by the Development Assistance Committee (DAC) of the Organisation for Economic Co-operation and Development (OECD) eligible for Official Development Assistance, 2017 data (ODA list).

${ }^{3}$ Studies of equids for agricultural use: defined as equids that provide support to farmers in developing countries for example carrying feed and water for livestock and connecting farmers to cooperatives and markets (Brooke, 2015).

${ }^{4}$ Experimental/quasi-experimental studies: experimental studies defined as studies which compare different treatments, where the researcher controls treatments using a randomised controlled study or control groups. Quasi-experimental studies defined as those that compare different treatments where the treatments are not randomised or are not controlled by the researcher (e.g. comparing responses pre and post-treatment in same patient). 
Information sources and search strategy

A literature search was performed on 13.11.17 and updated on 11.04.19 using CAB Abstracts (1910-present) and Medline (1946-present), which have been reported as the two key databases for veterinary literature (Grindlay et al., 2012). The following search terms were used: human, person, people, individual, horse, equine, equid, equus, equi, relationship, bond, interaction. All references were downloaded and managed in Endnote reference manager (Endnote X8.0.1).

\section{Selection of sources of evidence}

Any duplicate papers were removed and the titles were reviewed by the primary researcher ( $\mathrm{H}$. Clough). Publications were retained if the titles contained terms relating to the horse-human relationship. Any titles that were ambiguous were retained for abstract review. Abstracts were reviewed and retained if they related to studies of factors associated with the horse-human relationship and the search terms described above. Any studies identified during the abstract review that did not have the full text available were excluded. Any abstracts that were ambiguous were retained for full text review. The full text of included publications were then reviewed against inclusion and exclusion criteria (Table 1 ) by two researchers (H. Clough and S. Freeman) to agree the final included studies (Figure 1).

\section{Data charting process and data items}

The included publications were analysed to generate data extraction tables for the methods and population characteristics of each of the publications. Data extracted for study methods were: title; author; study methodology; aims; measures; and key outcomes as self-reported by the authors. Data extracted on study populations were: author and date; location; study participants; population size; and study perspective. The study perspective was established by identifying the study population and objectives.

No additional analysis was conducted. Methodological quality or risk of bias of included studies was not appraised, consistent with guidance on scoping review conduct (Arksey and O'Malley, 2005; Tricco et al., 2018).

\section{RESULTS}

\section{Selection of sources of evidence}

A total number of 5018 studies were found on the initial database searches. There were 132 papers included after the abstract check, however only 112 of these had the full text available (Figure 1). From these 112 full text publications, 85 studies were excluded from final analysis as they did not meet the final inclusion criteria (Table 1); the excluded studies were 33 reviews (two of which were systematic reviews), 14 studies of animalassisted therapies, six studies of working equids, 28 experimental or quasi-experimental studies and four studies which did not investigate the horse-human relationship (Figure 1). There were 27 papers which met the final inclusion criteria and were therefore analysed and data presented in extraction tables comparing study, method and population characteristics. 


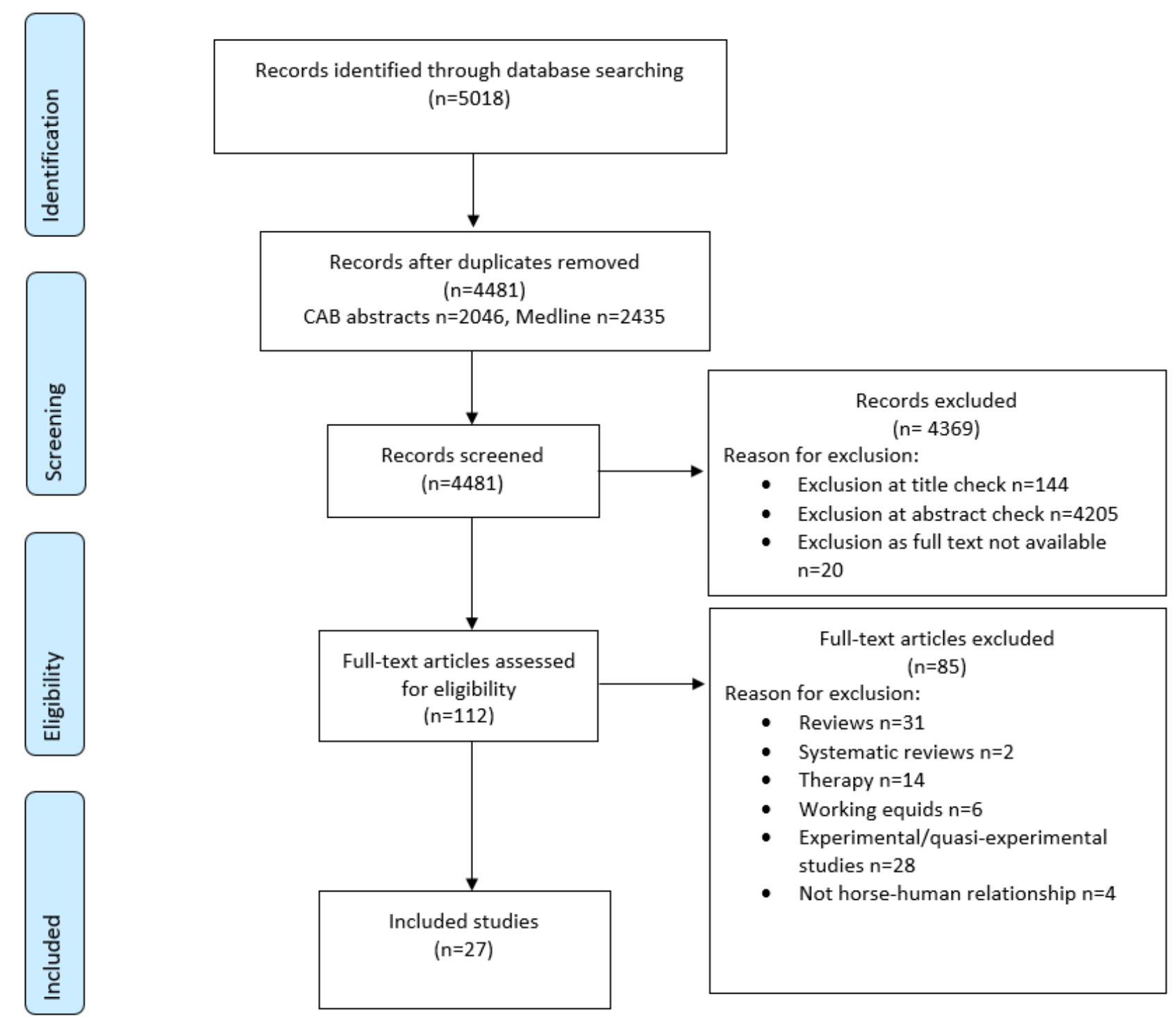

Figure 1: PRISMA flow diagram demonstrating the process used for a scoping review on the current literature exploring the horse-human relationship and how the final 27 included studies were identified.

From: Moher et al., The PRISMA Group (2009).

\section{Characteristics of source of evidence}

The data regarding the study methodology for each of the 27 included studies are presented in Table 2. A range of different study methods were used, including questionnaires $(n=11)$, behavioural observational studies ( $n=7)$, focus groups $(n=1)$, ethnographic studies $(n=5)$, interviews $(n=2)$ and mixed methods $(n=1)$.

The measures used in the studies included: thematic analysis $(n=7)$; instrument, tool or scale $(n=4)$; behavioural scoring $(n=4)$; mixed measures $(n=3)$; open and closed questions $(n=4)$; interview scoring guide $(n=1)$; Likert/VAS scale $(n=1)$; component analysis of data $(n=1)$; physiological parameters $(n=1)$; and behavioural scoring and physiological parameters $(n=1)$ (Table 2$)$.

The aims of each of the studies were all individual. There were no studies investigating the same or similar aims and objectives, but there were some similarities between studies and the areas in which they explored. These areas included: the effect of humans on equine behaviour and reactions $(n=5)$; equine training 
methodologies and behaviour $(n=4)$; horses within sport and leisure $(n=4)$; equine welfare $(n=3)$; human attachments and bonds to horses $(n=3)$; horse-human ecologies $(n=2)$; the influence of human-animal relationship on psychological wellbeing $(n=2)$; equine euthanasia $(n=2)$; the importance of personality traits to breeders $(n=1)$; and colic decisions ( $n=1)$ (Table 2 ). 


\begin{tabular}{|c|c|c|c|c|c|}
\hline Publication title & Author & $\begin{array}{l}\text { Methodology/ } \\
\text { study design }\end{array}$ & Aim of study & Measures & Important outcomes \\
\hline $\begin{array}{l}\text { Equine } \\
\text { gatekeepers, } \\
\text { animal narratives } \\
\text { and foxhunting } \\
\text { landscapes }\end{array}$ & Acton, A. & $\begin{array}{l}\text { Ethnographic } \\
\text { study }\end{array}$ & $\begin{array}{l}\text { Exploration of the } \\
\text { connection between } \\
\text { mounted fox hunting packs } \\
\text { and the landscape. }\end{array}$ & $\begin{array}{l}\text { Narratives of past and } \\
\text { present foxhunters to give } \\
\text { an ethnographic account of } \\
\text { the role of the horse in the } \\
\text { fox hunting culture. }\end{array}$ & $\begin{array}{l}\text { Using animals as 'co-actors' rather than subjects in } \\
\text { ethnographic approaches promoted appreciation of the } \\
\text { environment and the animals within it. }\end{array}$ \\
\hline $\begin{array}{l}\text { Living the 'Best Life' } \\
\text { or 'One Size Fits All' } \\
\text { - Stakeholder } \\
\text { Perceptions of } \\
\text { Racehorse Welfare }\end{array}$ & $\begin{array}{l}\text { Butler, D. et } \\
\text { al. }\end{array}$ & Focus groups & $\begin{array}{l}\text { Exploring the perceptions of } \\
\text { stakeholder in the British } \\
\text { racing industry of factors } \\
\text { influencing racehorse } \\
\text { welfare. }\end{array}$ & $\begin{array}{l}\text { Thematic analysis of three } \\
\text { areas: 'best life' and } \\
\text { minimum welfare } \\
\text { standards; main welfare } \\
\text { challenges; and innovative } \\
\text { practices to improve } \\
\text { welfare. }\end{array}$ & $\begin{array}{l}\text { Overall consensus on minimum welfare standards and } \\
\text { 'best life'. Important of tailoring plans for individuals } \\
\text { highlighted. 'Best life' scenario relies on horse-human } \\
\text { relationship to implement, monitor and change as } \\
\text { needed. }\end{array}$ \\
\hline $\begin{array}{l}\text { Companion animals } \\
\text { as selfobjects }\end{array}$ & Brown, S.E. & $\begin{array}{l}\text { Semi- } \\
\text { structured } \\
\text { interviews }\end{array}$ & $\begin{array}{l}\text { Exploring if self-psychology } \\
\text { can be systematically applied } \\
\text { to human-animal } \\
\text { relationships. }\end{array}$ & $\begin{array}{l}\text { Scoring guide to selfobject } \\
\text { type was developed and } \\
\text { used on the interview } \\
\text { transcripts. }\end{array}$ & $\begin{array}{l}\text { Self-psychology could be successfully applied to the } \\
\text { human-animal relationship. In this study, animals were } \\
\text { found to rival or surpass humans in the ability to } \\
\text { provide self-object needs. }\end{array}$ \\
\hline
\end{tabular}


An investigation of human-animal

interactions and empathy as related to pet preference, ownership, attachment, and attitudes in children

Tools of the trade or part of the family? Horses in competitive equestrian sport
Investigation of the

Five

Daly, B. and

Morton, L.L.

instrument

questionnaire

relationship between

children and pets in regards

to pet preference,

ownership, attachment and

attitudes.

Dashper, K.

Ethnographic

study

Exploring horses in

and altering the horse-
The pet ownership survey

(Daly and Morton, 2003)

The Bryant Index of

Empathy (1982)

The pet preference

inventory (Daly and

Morton, 2003)

The Lexington Attachment

to Pets Scale (Johnson et

al., 1992)

The Pet Attitude Scale

(Templer et al., 1981).

Loosely structured

interviews around four

broad themes: participants'

involvement in equestrian

competitive equestrian sport

human relationship. sport, how that

involvement fits in with or clashes with other areas of
Those who were highly attached to their pets were more empathetic than those who were less attached. Girls were more empathetic than boys. Empathy was higher for those who expressed a preference for horses and birds.

The emerging key themes included: the changing life, goals and motivations within the sport, and attitudes to the horses they ride. nature of equestrian sport; the influence of owners and the feelings of mutual respect and affection that can develop between horses and humans. 


\begin{tabular}{|c|c|c|c|c|c|}
\hline $\begin{array}{l}\text { Listening to horses: } \\
\text { Developing } \\
\text { attentive } \\
\text { interspecies } \\
\text { relationships } \\
\text { through sport and } \\
\text { leisure }\end{array}$ & Dashper, K. & $\begin{array}{l}\text { Ethnographic } \\
\text { study }\end{array}$ & $\begin{array}{l}\text { Considering some ways in } \\
\text { which human participants } \\
\text { try to develop attentive } \\
\text { relationships with their } \\
\text { equine partners. }\end{array}$ & $\begin{array}{l}\text { Transcription and thematic } \\
\text { analysis of interviews and } \\
\text { field notes taken in a three- } \\
\text { year period. }\end{array}$ & $\begin{array}{l}\text { Participants were acutely aware of their horses as } \\
\text { individuals with personalities, likes, dislikes and how } \\
\text { this impacted owners' decision making ability. Horses } \\
\text { were described by the participants as 'persons'. } \\
\text { Emerging themes included: guardianship, affection and } \\
\text { relationship building. }\end{array}$ \\
\hline $\begin{array}{l}\text { "Riding up forested } \\
\text { mountain sides, in } \\
\text { wide open spaces, } \\
\text { and with walls": } \\
\text { developing an } \\
\text { ecology of horse- } \\
\text { human } \\
\text { relationships }\end{array}$ & $\begin{array}{l}\text { Davis,D. et } \\
\text { al. }\end{array}$ & $\begin{array}{l}\text { Ethnographic } \\
\text { study }\end{array}$ & $\begin{array}{l}\text { To demonstrate the complex } \\
\text { ways in which riding terrains } \\
\text { affect shared ecologies of } \\
\text { horse-rider relations, } \\
\text { identities, and psyches. }\end{array}$ & $\begin{array}{l}\text { Analysis of narrative data } \\
\text { using a grounded, practice } \\
\text { theory. }\end{array}$ & $\begin{array}{l}\text { Dressage riders were described as becoming attuned, } \\
\text { focused and in touch with their horses. Event riders } \\
\text { described the importance of shared trust, fearlessness } \\
\text { and their confidence in the horse. Endurance riders } \\
\text { were described as relating stamina, conditioning and } \\
\text { stoic endurance for survival. Overall finding that horse } \\
\text { and human paired together, defined, distinguished, and } \\
\text { identified by the environments that they were in. }\end{array}$ \\
\hline $\begin{array}{l}\text { Training } \\
\text { methodologies } \\
\text { differ with the } \\
\text { attachment of } \\
\text { humans to horses }\end{array}$ & $\begin{array}{l}\text { DeAraugo ,J. } \\
\text { et al. }\end{array}$ & Questionnaire & $\begin{array}{l}\text { Using attachment theory to } \\
\text { investigate whether the } \\
\text { attachment between rider or } \\
\text { handler and horse differed } \\
\text { according to the preferred } \\
\text { training method. }\end{array}$ & $\begin{array}{l}\text { Nine items used to assess } \\
\text { attachment using a seven } \\
\text { point scale. Scores were } \\
\text { calculated for avoidance } \\
\text { and anxiety and statistically } \\
\text { analysed. }\end{array}$ & $\begin{array}{l}\text { Behavioural training participants scored more highly on } \\
\text { the attachment-avoidance scores. The behavioural and } \\
\text { eclectic training methods were associated with higher } \\
\text { levels of education. }\end{array}$ \\
\hline
\end{tabular}




\begin{tabular}{|c|c|c|c|c|c|}
\hline $\begin{array}{l}\text { Examining } \\
\text { Canadian equine } \\
\text { industry } \\
\text { participants' } \\
\text { perceptions of } \\
\text { horses and their } \\
\text { welfare }\end{array}$ & $\begin{array}{l}\text { DuBois, C. et } \\
\text { al. }\end{array}$ & Questionnaire & $\begin{array}{l}\text { Exploring the perceptions of } \\
\text { horse sentience and welfare } \\
\text { status of animals in the } \\
\text { Canadian equine industry. }\end{array}$ & $\begin{array}{l}39 \text { questions on } \\
\text { participants demographic } \\
\text { and experience, and their } \\
\text { opinions on sentience and } \\
\text { welfare, including use of } \\
\text { scenarios. }\end{array}$ & $\begin{array}{l}\text { Horses were mainly considered companion animals, } \\
\text { and most participants strongly believed horses could } \\
\text { feel pain, fear and boredom. Participants agreed that } \\
\text { there were welfare issues within the issues, specifically } \\
\text { horse that were unwanted, not trained appropriately, } \\
\text { or there was a lack of knowledge by the owner/care } \\
\text { giver. Participants' opinions were affected by the role } \\
\text { they assigned to horses and how they were involved in } \\
\text { the equine industry. }\end{array}$ \\
\hline $\begin{array}{l}\text { Importance of } \\
\text { personality traits in } \\
\text { horses to breeders } \\
\text { and riders }\end{array}$ & Graf,P. et al. & $\begin{array}{l}\text { Online } \\
\text { questionnaire }\end{array}$ & $\begin{array}{l}\text { Evaluating the importance of } \\
\text { personality traits in horse to } \\
\text { breeders and riders. }\end{array}$ & $\begin{array}{l}41 \text { item web-based } \\
\text { questionnaire containing } \\
\text { open and closed questions } \\
\text { and Likert and ranking } \\
\text { scales. }\end{array}$ & $\begin{array}{l}\text { Temperament, character traits and willingness to work } \\
\text { were assigned more weight. Less weight was given to } \\
\text { performance traits like quality of trot or show-jumping. } \\
\text { The relative weighting of traits varied between the } \\
\text { different groups of rider. Ease of daily work, safer } \\
\text { handling and horse-human relationship were } \\
\text { commonly listed in answer to why personality traits are } \\
\text { important. }\end{array}$ \\
\hline
\end{tabular}


A brief note on some possible factors involved in the reactions of

horses to humans

Equipment and training risk factors associated with ridden behaviour problems in UK leisure horses
Assessing the possible factors involved in the reactions of horses to humans.
Observation and scoring of posture using Waring and Dark's (1978) observations.

16 questions regarding the type of work undertaken with the horse, the types of equipment and training methods used on it and the regularity that professional services (farriers, saddlers and dentistry professionals) were employed. Respondents were also asked to assess the frequency that their horse performed 15 different behavioural problems over the last week it was ridden using rating scales.
More horses showed a friendly behaviour opposed to an aggressive behaviour towards an unfamiliar human. Inter-individual variations in reaction were clear and had a good consistency. Factors involved in those variations included the breed and the usual caretaker. Horses depending on the same caretaker for their daily routine were found to have similar responses which differed from that of other groups.

Risk factors associated with the ridden behaviour problems included: the design and fit of the saddle, with dressage and working hunter saddles associated with a reduced risk of ridden behaviour problems compared to general purpose saddles. The horse's foot care and shoeing routine was associated with three of the four groups with behavioural problems. An increased time (7 weeks or more) between farrier visits was associated with an increased risk of discomfort behaviour. The use of artificial training aids was associated with an increased risk of behaviour problems. Spending more time with the horse outside of training situations was associated with a reduced risk of problems. 
The strengths of

statistical

techniques in

identifying patterns

underlying

apparently random

behavioural

problems in horses

Stranger danger?

An investigation

into the influence

of human-horse

bond on stress and

behaviour
Hockenhull,

of an online

(b)

questionnaire

Determining how principal components analysis has

been used to identify

relationships underlying

individual behavioural

problems in horses.

Determining whether horses' owners confer a 'safe-base' and improve horse

ljichi, C. et

Behavioural

and

al. physiological

measures
Factors influencing

the attitude of

equestrians

horse welfare towards sport

\section{Ikinger, C. et Online}

al.
Principal component analysis of data from three linked cross-sectional questionnaires.

Measures of behaviour, eye temperature and heart rate whilst navigating novel obstacles with owner or unfamiliar handler.

44 individual behavioural problems, including stable related and handling behavioural problems, pre-feeding behavioural problems, and ridden behavioural problems, were reduced to 12 behavioural problem components. Each component was composed of groups with behavioural problems that may share a common underlying aetiology. The study findings demonstrated the value of statistical techniques in identifying associations between apparently random behavioural problems.

There was no statistically significant difference in the behavioural or physiological measures of stress between when the horses were handled by their owner or an unfamiliar person.

The factors with the greatest impact on attitudes to horse welfare were the affection for animals, the attitude towards 'classically organised' equestrianism

Assessing factors influencing 150 questions with the the attitude of equestrians towards sport horse welfare.

\section{majority using five point}

Likert scale. and the utility orientation. Gender, income, agricultural background, tradition, brand orientation and the importance of breed and pedigree were also found to have a significant influence. Age and involvement in horse-riding as a hobby were found to have no effect on attitudes to horse welfare. 


\begin{tabular}{|c|c|c|c|c|c|}
\hline $\begin{array}{l}\text { Separating a horse } \\
\text { from the social } \\
\text { group for riding or } \\
\text { training purposes: a } \\
\text { descriptive study of } \\
\text { human-horse } \\
\text { interactions }\end{array}$ & $\begin{array}{l}\text { Jorgensen, } \\
\text { G.H.M. et al. }\end{array}$ & $\begin{array}{l}\text { Behavioural } \\
\text { observation }\end{array}$ & $\begin{array}{l}\text { Determining the difficulty of } \\
\text { haltering and separating a } \\
\text { horse from a group for riding } \\
\text { or trainer purposes and how } \\
\text { horse-human interactions } \\
\text { could affect this. }\end{array}$ & $\begin{array}{l}\text { In each group, the horse } \\
\text { owner or keeper (handler) } \\
\text { was asked to enter the } \\
\text { group, approach his/her } \\
\text { horse, halter it and lead it } \\
\text { out through the gate, then } \\
\text { keep the horse standing } \\
\text { out of sight from other } \\
\text { horses for } 2 \text { minutes. } \\
\text { Interactions were video } \\
\text { recorded and behaviours } \\
\text { were scored. }\end{array}$ & $\begin{array}{l}\text { Only } 1 \text { out of } 100 \text { horses moved away from the handler } \\
\text { when approached. } 96 \% \text { of the target horses followed } \\
\text { their handler without showing any resistance. In } 75 \% \text { of } \\
\text { the tests, the other horses did not interact with the } \\
\text { target horse and/or handler. Separating a horse from } \\
\text { its group can be considered relatively safe and } \\
\text { unproblematic if there are good management practices } \\
\text { and trained handlers. }\end{array}$ \\
\hline $\begin{array}{l}\text { Investigating horse- } \\
\text { human } \\
\text { interactions: the } \\
\text { effect of a nervous } \\
\text { human }\end{array}$ & $\begin{array}{l}\text { Keeling, L.J. } \\
\text { et al. }\end{array}$ & $\begin{array}{l}\text { Behavioural } \\
\text { observation }\end{array}$ & $\begin{array}{l}\text { Evaluating the effect of a } \\
\text { nervous human on horse- } \\
\text { human interactions. }\end{array}$ & $\begin{array}{l}\text { Heart rates and direct } \\
\text { behavioural observations } \\
\text { made and scored on a } \\
\text { three, four or five point } \\
\text { scale. }\end{array}$ & $\begin{array}{l}\text { There was an increase in heart rate for both the person } \\
\text { and the horse when walking past a potentially } \\
\text { challenging situation. The findings indicate that analysis } \\
\text { of heart rate recorded simultaneously from people and } \\
\text { horses under different experimental handling or riding } \\
\text { conditions presents a useful tool to investigate horse- } \\
\text { human interactions. }\end{array}$ \\
\hline $\begin{array}{l}\text { My Horse Is My } \\
\text { Therapist: The } \\
\text { medicalization of } \\
\text { pleasure among } \\
\text { women equestrians }\end{array}$ & $\begin{array}{l}\text { Lee Davis, D. } \\
\text { et al. }\end{array}$ & $\begin{array}{l}\text { Ethnographic } \\
\text { study }\end{array}$ & $\begin{array}{l}\text { Exploring the role that } \\
\text { horse-human interactions } \\
\text { may play in well-being and } \\
\text { impairment among a sample } \\
\text { of everyday riders. }\end{array}$ & $\begin{array}{l}\text { Thematic analysis of } \\
\text { lifecycle narratives. }\end{array}$ & $\begin{array}{l}\text { The themes that were identified included: pleasure; } \\
\text { fun; joy; benefits; and therapies. }\end{array}$ \\
\hline
\end{tabular}




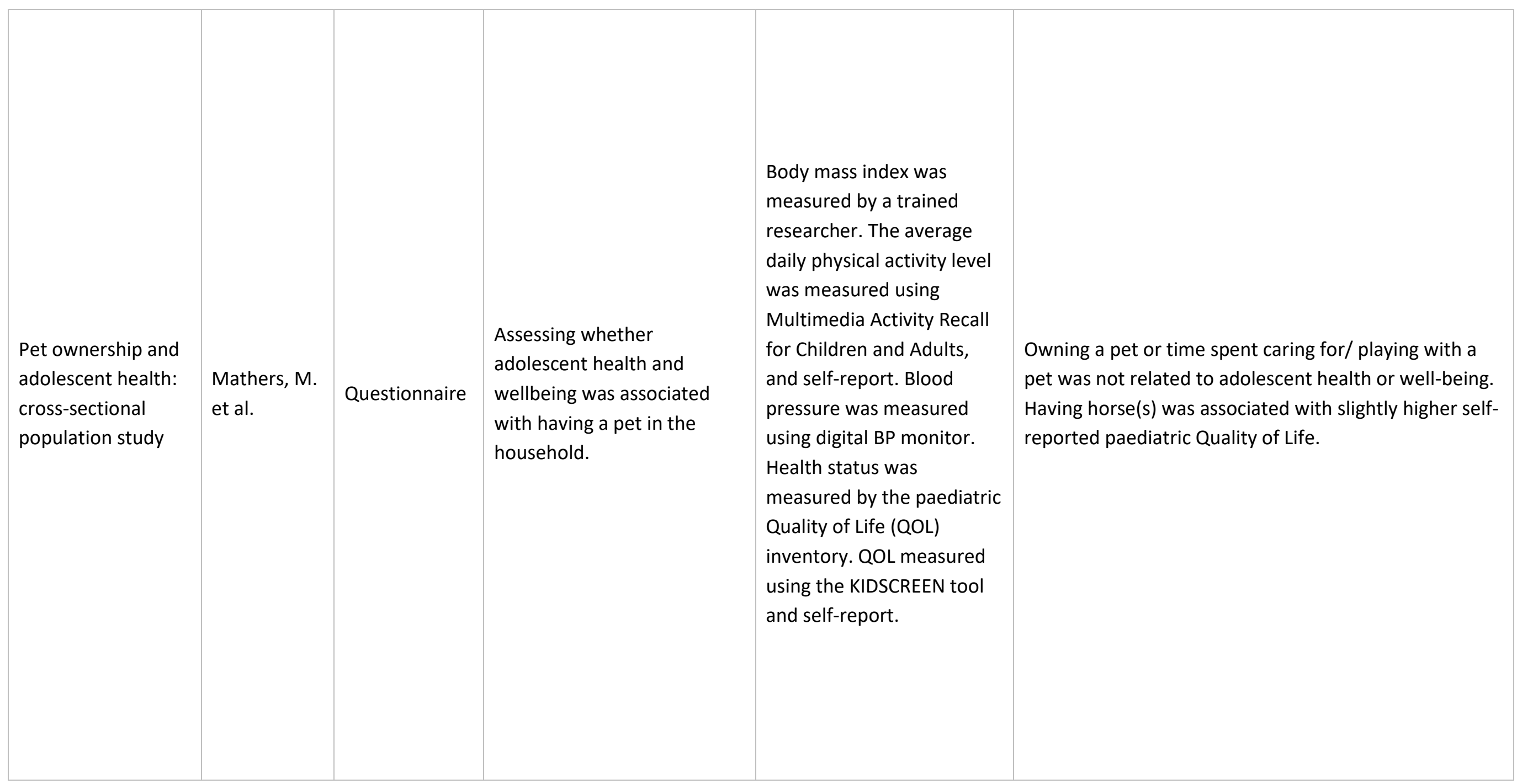

Vol 4, Issue 4

10.18849/VE.V4I4.240 
Euthanasia in aged horses: relationship between the owner's personality and their opinions on, and experience of, euthanasia of horses
Exploring the relationship between the owner's

McGowan, T.W. et al.

Questionnaire personality and their opinions on, and experience of, euthanasia of horses.
Questionnaire on euthanasia of horses and a self-assessment five factor personality test.
Most owners considered euthanasia of a horse to be a difficult decision, which they based on the horse's current health, anticipated future quality of life, and veterinary advice. Owners reported the loss to be a distressing experience rather than providing a sense of relief. Female owners who found it more difficult to make the decision were more likely to have neurotic personalities and based their decision more on their relationship with the horse and the horse's quality of life. Veterinarians play an important role in the diagnosis of health factors that influence the decision to euthanase. The personality of the owner may influence the extent to which they find euthanasia distressing, especially in female horse owners.

Geriatric horses were more frequently consider to be companion animals, retired or part of a business compared to non-geriatric. No significant differences in degree of horse-human attachment between geriatric and non-geriatric horses. Higher levels of bereavement associated with euthanasia compared to when horses died, and for geriatric horses compared to nongeriatric. Participants made a number of accommodations for their care and management of geriatric horses.
Exploring the relationship between horse owners/lessees and geriatric (>20-years-old) or nongeriatric horses, and factors influencing veterinary care decision making.
Online questionnaire using human-horse attachment scale, and modified version of Pet Bereavement Questionnaire, as well as owner and horse demographics and details of veterinary care. 


\begin{tabular}{|c|c|c|c|c|c|}
\hline $\begin{array}{l}\text { Cross-modal } \\
\text { perception of } \\
\text { human emotion in } \\
\text { domestic horses } \\
\text { (Equus caballus) }\end{array}$ & $\begin{array}{l}\text { Nakamura, } \\
\text { K. et al. }\end{array}$ & $\begin{array}{l}\text { Behavioural } \\
\text { observation }\end{array}$ & $\begin{array}{l}\text { Investigating whether horses } \\
\text { can cross-modally perceive } \\
\text { human emotions. }\end{array}$ & $\begin{array}{l}\text { Horses were shown human } \\
\text { facial expressions on } \\
\text { screen and voices from a } \\
\text { speaker from their } \\
\text { caretaker or stranger using } \\
\text { positive (happy/gentle) or } \\
\text { negative (angry/scolding) } \\
\text { expressions. These were } \\
\text { played in the congruent } \\
\text { condition (both audio and } \\
\text { visual, positive or both } \\
\text { negative) and incongruent } \\
\text { (e.g. positive facial } \\
\text { expression with negative } \\
\text { voice) conditions. Horses } \\
\text { behavioural response } \\
\text { measured by total looking } \\
\text { time and response latency. }\end{array}$ & $\begin{array}{l}\text { Horses looked at the screen for longer when the } \\
\text { caretaker incongruency condition was used compared } \\
\text { to the congruency condition. Horses looked at the } \\
\text { speaker faster with incongruent condition compared to } \\
\text { congruent condition for both caretaker and stranger. } \\
\text { Study concluded that horses can cross-modally } \\
\text { recognise emotions of both caretakers and strangers. }\end{array}$ \\
\hline $\begin{array}{l}\text { Could it be colic? } \\
\text { Horse-owner } \\
\text { decision making } \\
\text { and practices in } \\
\text { response to equine } \\
\text { colic }\end{array}$ & $\begin{array}{l}\text { Scantlebury, } \\
\text { C.E. et al. }\end{array}$ & $\begin{array}{l}\text { Mixed- } \\
\text { methods: } \\
\text { interviews and } \\
\text { cross sectional } \\
\text { questionnaire }\end{array}$ & $\begin{array}{l}\text { Assessing horse owner } \\
\text { decision making in response } \\
\text { to equine colic. }\end{array}$ & $\begin{array}{l}15 \text { interviews were } \\
\text { analysed to conceptualise } \\
\text { the processes involved in } \\
\text { horse-owner management } \\
\text { of colic. Cross sectional } \\
\text { survey of } 673 \text { horse owners } \\
\text { designed to test the } \\
\text { concepts found. }\end{array}$ & $\begin{array}{l}\text { Veterinary-client communication was important during } \\
\text { a colic episode in assisting owners during the decision } \\
\text { making process. From the interviews, the cost of } \\
\text { veterinary assistance and treatment influenced the } \\
\text { timing of the decision to call the veterinary surgeon and } \\
\text { consenting to surgery. Money was not an influencing } \\
\text { factor in the survey. }\end{array}$ \\
\hline
\end{tabular}




\begin{tabular}{|c|c|c|c|c|c|}
\hline $\begin{array}{l}\text { Behaviour patterns } \\
\text { of horses can be } \\
\text { used to establish a } \\
\text { dominant- } \\
\text { subordinate } \\
\text { relationship } \\
\text { between man and } \\
\text { horse }\end{array}$ & $\begin{array}{l}\text { Sighieri, C. et } \\
\text { al. }\end{array}$ & $\begin{array}{l}\text { Behavioural } \\
\text { observation }\end{array}$ & $\begin{array}{l}\text { Investigating how humans } \\
\text { can enter the social } \\
\text { hierarchy of the horse by } \\
\text { mimicking the behaviour and } \\
\text { stance it uses to establish } \\
\text { dominance. }\end{array}$ & $\begin{array}{l}\text { Methods based on the } \\
\text { three elements } \\
\text { fundamental to the } \\
\text { equilibrium of the herd: } \\
\text { flight, herd instinct and } \\
\text { hierarchy. The trainer- } \\
\text { horse relationship was } \\
\text { established in three } \\
\text { phases: retreat, approach } \\
\text { and association. Response } \\
\text { time was measured for } \\
\text { each phase. }\end{array}$ & $\begin{array}{l}\text { All horses responded to their trainer. } 4 / 5 \text { completed } \\
\text { the three phases (retreat, approach and association) on } \\
\text { the same day. One horse took several days, however all } \\
\text { phases were completed. Observations suggest that it is } \\
\text { possible to manage unhandled horses without coercion } \\
\text { by mimicking their behavioural patterns. }\end{array}$ \\
\hline $\begin{array}{l}\text { Austrian } \\
\text { Veterinarians' } \\
\text { Attitudes to } \\
\text { Euthanasia in } \\
\text { Equine Practice }\end{array}$ & $\begin{array}{l}\text { Springer, S. } \\
\text { et al. }\end{array}$ & Questionnaire & $\begin{array}{l}\text { Examining Austrian equine } \\
\text { veterinarians attitudes to } \\
\text { equine euthanasia in a range } \\
\text { of scenarios and identifying } \\
\text { factors affecting end of life } \\
\text { decisions. }\end{array}$ & $\begin{array}{l}\text { Online questionnaire with } \\
56 \text { questions covering } \\
\text { demographic information, } \\
\text { medical/technical, } \\
\text { agreement with normative } \\
\text { and descriptive } \\
\text { statements, case scenarios } \\
\text { and open-ended questions. }\end{array}$ & $\begin{array}{l}\text { Veterinarians consider medical, social and economic } \\
\text { factors to be of great importance on the decision } \\
\text { making process and especially recognise the impact of } \\
\text { the emotional bond between horse and owner. } \\
\text { Requests for 'convenience' euthanasia (including } \\
\text { changed circumstances, last will of the owner and } \\
\text { financial reasons) are typically rejected. Participants' } \\
\text { gender, duration of working experience, and the } \\
\text { proportion of their working time spent with horses was } \\
\text { significantly associated with responses to euthanasia } \\
\text { scenarios. }\end{array}$ \\
\hline
\end{tabular}




\begin{tabular}{|l|l|l|l|l|l|}
\hline $\begin{array}{l}\text { Over-riding } \\
\text { concerns: } \\
\text { developing safe } \\
\text { relations in the } \\
\text { high-risk } \\
\text { interspecies sport } \\
\text { of eventing }\end{array}$ & $\begin{array}{l}\text { Thompson, } \\
\text { K. et al. }\end{array}$ & Interviews & $\begin{array}{l}\text { Developing safe human- } \\
\text { horse horse-human } \\
\text { relationships in eventing by } \\
\text { understanding how risk } \\
\text { perception and experience } \\
\text { subjectively is implicated in } \\
\text { through and by the horse- } \\
\text { human relationship. }\end{array}$ & $\begin{array}{l}\text { Immersion, coding, } \\
\text { categorising and } \\
\text { generation of themes. The } \\
\text { analysis of the interviews } \\
\text { was sensitised around the } \\
\text { perceptions of risk, } \\
\text { experience of risk, rider } \\
\text { concerns and rider } \\
\text { mitigation. }\end{array}$ & $\begin{array}{l}\text { Findings were consistent with the following three } \\
\text { theories of voluntary risk taking: edgework; sensation- } \\
\text { seeking; and flow. Further mixed methods research has } \\
\text { been suggested to fully evaluate the use of existing risk } \\
\text { theory for understanding participant experiences of } \\
\text { high-risk sports like eventing. }\end{array}$ \\
$\begin{array}{l}\text { Developing a horse } \\
\text { welfare assessment } \\
\text { protocol }\end{array}$ & $\begin{array}{l}\text { Viksten, S.M. } \\
\text { et al. }\end{array}$ & $\begin{array}{l}\text { Behavioural } \\
\text { observation }\end{array}$ & $\begin{array}{l}\text { Development of a horse } \\
\text { welfare assessment } \\
\text { protocol. }\end{array}$ & $\begin{array}{l}\text { 15 animal based, 24 } \\
\text { resource based and eight } \\
\text { management based } \\
\text { measures used. This was } \\
\text { repeated after 16-25 days } \\
\text { with the same horses. }\end{array}$ & $\begin{array}{l}\text { The ability to use this assessment tool for up to 22 } \\
\text { horses a day. Changes to draft protocol were made and } \\
\text { include an ethogram to assess the human-animal } \\
\text { relationship. }\end{array}$ \\
\hline
\end{tabular}

Table 2: Data extraction table for method characteristics of 27 publications that met the final inclusion criteria for a scoping review of literature exploring the horse-human relationship. 


\section{Population characteristics}

Table 3 presents the population characteristics of these studies. All 27 studies were published within the last 17 years. Fifteen studies were published within the last 5 years (2014-2019), eight studies were published between 2009 and 2013 and four studies were published before 2009. The majority of these studies were carried out in Europe $(n=15)$, with eight of these conducted in the UK. Most studies focused on one perspective rather than the two-way interaction involved in the horse-human relationship; perspective of the human $(n=20)$, perspective of horses $(n=6)$, perspective of both $(n=1)$ (Table 3 ).

\begin{tabular}{|c|c|c|c|c|}
\hline $\begin{array}{l}\text { Author and } \\
\text { year of } \\
\text { publication }\end{array}$ & Location & Participants & $\begin{array}{l}\text { Total population size } \\
\text { (Number relating to } \\
\text { horse in multi- } \\
\text { species studies) }\end{array}$ & Perspective \\
\hline Acton (2014) & England, UK & $\begin{array}{l}\text { Horse, rider and } \\
\text { landscape in } \\
\text { foxhunting culture }\end{array}$ & N/A & Human \\
\hline $\begin{array}{l}\text { Butler et al. } \\
\text { (2019) }\end{array}$ & England, UK & $\begin{array}{l}\text { Trainers, owners, vets, } \\
\text { stable staff, equine } \\
\text { charity, Racing Welfare } \\
\text { and British Horse } \\
\text { Racing Authority staff }\end{array}$ & 42 & Human \\
\hline Brown (2007) & Alabama, USA & $\begin{array}{l}\text { Members of a social } \\
\text { media group for } \\
\text { rescuing horses }\end{array}$ & $\begin{array}{l}24 \text { (10 interviews } \\
\text { pertained to horses) }\end{array}$ & Human \\
\hline $\begin{array}{l}\text { Daly and } \\
\text { Morton } \\
\text { (2006) }\end{array}$ & Ontario, Canada & $\begin{array}{l}\text { Children aged 8-14 } \\
\text { years }\end{array}$ & $\begin{array}{l}155 \\
\text { ( } 58 \text { stated preference } \\
\text { for horse as a pet) }\end{array}$ & Human \\
\hline $\begin{array}{l}\text { Dashper } \\
\text { (2014) }\end{array}$ & England, UK & Elite horse riders & 26 & Human \\
\hline $\begin{array}{l}\text { Dashper } \\
\text { (2017) }\end{array}$ & England, UK & $\begin{array}{l}\text { Amateur horse riders } \\
\text { and caregivers }\end{array}$ & 17 & Human \\
\hline $\begin{array}{l}\text { Davis et al. } \\
\text { (2013) }\end{array}$ & $\begin{array}{l}\text { Midwestern, USA and } \\
\text { Northern Norway }\end{array}$ & $\begin{array}{l}\text { Horse people } \\
\text { competing in different } \\
\text { disciplines }\end{array}$ & 60 & Human \\
\hline $\begin{array}{l}\text { DeAraugo et } \\
\text { al. (2014) }\end{array}$ & Global & $\begin{array}{l}\text { Horse riders and } \\
\text { handlers }\end{array}$ & 538 & Human \\
\hline $\begin{array}{l}\text { DuBois et al. } \\
\text { (2018) }\end{array}$ & Canada & $\begin{array}{l}\text { Canadian citizens, over } \\
18 \text { years of age, with } \\
\text { an interest in horses }\end{array}$ & 901 & Human \\
\hline $\begin{array}{l}\text { Graf et al. } \\
(2013)\end{array}$ & Global & $\begin{array}{l}\text { Sport riders, leisure } \\
\text { riders, and breeders }\end{array}$ & 1087 participants & Human \\
\hline $\begin{array}{l}\text { Hausberger } \\
\text { and Muller } \\
(2002)\end{array}$ & Saumur, France & Adult horses & $\begin{array}{l}224 \text { horses of mixed } \\
\text { breeds }\end{array}$ & Horse \\
\hline
\end{tabular}




\begin{tabular}{|c|c|c|c|c|}
\hline $\begin{array}{l}\text { Hockenhull } \\
\text { and } \\
\text { Creighton } \\
\text { (2012a) }\end{array}$ & UK & $\begin{array}{l}\text { Leisure horse owners } \\
\text { and their horses }\end{array}$ & $\begin{array}{l}1326 \text { owner reports } \\
\text { on horses }\end{array}$ & Human \\
\hline $\begin{array}{l}\text { Hockenhull } \\
\text { and } \\
\text { Creighton } \\
\text { (2012b) }\end{array}$ & UK & $\begin{array}{l}\text { Leisure horse owners - } \\
\text { component analysis of } \\
\text { three studies }\end{array}$ & $\begin{array}{l}\text { Stable related and } \\
\text { handling - } 1230 \\
\text { horses } \\
\text { Pre-feeding } \\
\text { behaviour - } 890 \\
\text { horses } \\
\text { Ridden behaviour - } \\
791 \text { horses }\end{array}$ & Human \\
\hline $\begin{array}{l}\text { ljichi et al. } \\
(2018)\end{array}$ & Gloucestershire, UK & $\begin{array}{l}\text { Livery horses at } \\
\text { equestrian } \\
\text { establishment }\end{array}$ & $\begin{array}{l}46 \text { horses of mixed } \\
\text { breeds and } \\
\text { experiences }\end{array}$ & Horse \\
\hline $\begin{array}{l}\text { Ikinger et al. } \\
\text { (2016) }\end{array}$ & Germany & Riders & 2947 & Human \\
\hline $\begin{array}{l}\text { Jorgensen et } \\
\text { al. (2011) }\end{array}$ & Eastern Norway & Horses & $\begin{array}{l}20 \text { groups of horses } \\
\text { of mixed breeds }\end{array}$ & Horse \\
\hline $\begin{array}{l}\text { Keeling et al. } \\
\text { (2009) }\end{array}$ & Sweden & $\begin{array}{l}\text { Horses, handlers and } \\
\text { riders }\end{array}$ & $\begin{array}{l}\text { Leading }-10 \text { horses } \\
\text { of mixed breeds and } \\
20 \text { handlers } \\
\text { Riding }-17 \text { horses } \\
\text { and } 17 \text { riders }\end{array}$ & $\begin{array}{l}\text { Horse and } \\
\text { human }\end{array}$ \\
\hline $\begin{array}{l}\text { Lee Davis et } \\
\text { al. (2015) }\end{array}$ & $\begin{array}{l}\text { Midwestern USA and Arctic } \\
\text { Norway }\end{array}$ & $\begin{array}{l}\text { Non-professional } \\
\text { riders }\end{array}$ & $\begin{array}{l}60 \text { interviewed, } 52 \\
\text { lifestyle narratives } \\
\text { reported (interviews } \\
\text { from } 8 \text { men were not } \\
\text { analysed) }\end{array}$ & Human \\
\hline $\begin{array}{l}\text { Mathers et } \\
\text { al. (2010) }\end{array}$ & Victoria, Australia & Students aged $13-19$ & $\begin{array}{l}928 \text { students, } 61 \text { of } \\
\text { which owned horses }\end{array}$ & Human \\
\hline $\begin{array}{l}\text { McGowan et } \\
\text { al. (2012) }\end{array}$ & Queensland, Australia & $\begin{array}{l}\text { Horse owners of aged } \\
\text { horses }\end{array}$ & 111 owners & Human \\
\hline $\begin{array}{l}\text { Mueller et al. } \\
(2018)\end{array}$ & $\begin{array}{l}\text { Study conducted in USA - } \\
\text { geographical location of } \\
\text { participants not reported }\end{array}$ & $\begin{array}{l}\text { Horse owners who } \\
\text { owned/leased >1 } \\
\text { horse }\end{array}$ & 2395 participants & Human \\
\hline $\begin{array}{l}\text { Nakamura et } \\
\text { al. (2018) }\end{array}$ & Tokyo, Japan & $\begin{array}{l}\text { Horses and caretakers } \\
\text { from University } \\
\text { equestrian teams }\end{array}$ & $\begin{array}{l}19 \text { horses, their } \\
\text { caretakers and } \\
\text { strangers }\end{array}$ & Horse \\
\hline $\begin{array}{l}\text { Scantlebury } \\
\text { et al. (2014) }\end{array}$ & North West, UK & $\begin{array}{l}\text { Horse owners with } \\
\text { colic experience }\end{array}$ & $\begin{array}{l}15 \text { interviewees } \\
673 \text { horse owners - } \\
\text { questionnaire }\end{array}$ & Human \\
\hline $\begin{array}{l}\text { Sighieri et al. } \\
(2003)\end{array}$ & Arezzo, Italy & Unhandled mares & Five Haflinger mares & Horse \\
\hline
\end{tabular}




\begin{tabular}{|l|l|l|l|l|}
\hline $\begin{array}{l}\text { Springer et } \\
\text { al. } 2019\end{array}$ & Austria & $\begin{array}{l}\text { Member of the } \\
\text { Austrian Equine } \\
\text { Veterinary Association }\end{array}$ & $\begin{array}{l}64 \text { veterinarians } \\
\text { involved in equine } \\
\text { work }\end{array}$ & Human \\
\hline $\begin{array}{l}\text { Thompson } \\
\text { and Nesci } \\
(2016)\end{array}$ & Australia & Eventers & 21 participants & Human \\
\hline $\begin{array}{l}\text { Viksten et al. } \\
(2017)\end{array}$ & Sweden & $\begin{array}{l}\text { Swedish riding school } \\
\text { horses }\end{array}$ & $\begin{array}{l}37 \text { horses of mixed } \\
\text { breeds }\end{array}$ & Horse \\
\hline
\end{tabular}

Table 3: Data extraction table of population characteristics from 27 publications that met the final inclusion criteria of a scoping review of literature exploring the horse-human relationship.

\section{DISCUSSION}

The human animal relationship has become an increasingly popular area for scientific research (Hosey and Melfi, 2014; Dashper, 2017). Research in this area has predominantly explored the relationships that humans have with companion animals, and only more recently the relationship that humans have with horses. The exploration of the horse-human relationship through a scoping review identified a diverse and heterogeneous body of published literature. Scoping reviews, unlike systematic reviews, do not strive for evidence synthesis or appraisal of research quality of the studies, but instead pose a transparent and thorough map of research areas identified (Arksey and O'Malley, 2005). Heterogeneity across the 27 publications identified in this scoping review highlights the benefits of performing a scoping review prior to an extensive literature review. Very limited comparisons of aims, objectives and methodologies could be drawn across the publications, but this study provides the framework to define more specific research questions and systematic reviews for future research, by extracting key information and grouping and categorising data. The research areas identified by this review as having the most studies were: equine behaviour and reactions towards humans (5/27); equine training methodologies and behaviour (4/27) and horses within sport and leisure (4/27).

Broad search terms and inclusion criteria were used for this scoping review to gain an understanding of the current scientific research involving the horse-human relationship and what, if any, specific research areas could be identified. This also raised challenges: it led to a large variability in the studies that were identified using the search terms, including literature on working equids and animal-assisted therapies. It was decided after the initial database search and categorisation of research areas that these research areas would be excluded from the final scoping review, allowing the focus to remain on the relationship between humans and horses applicable to the main horse owning population within the UK. It is important however, to appreciate that the relationship humans have with working equids and the use of equids in animal-assisted therapies, are important areas of research within the horse-human relationship. These require further investigation to gain a better understanding of the available research within the areas themselves, independent of this study. The results of the initial searches from the scoping review highlighted the numbers of publications in each area, which will be helpful to inform future systematic reviews.

For this review, 27 studies met the inclusion criteria. Only two databases were used for the literature search; these databases were deemed the most appropriate for veterinary literature (Grindlay et al., 2012) and therefore most suitable for a scoping review. The searches used in this study did not identify some studies which would have met inclusions criteria for example; Chamove et al. (2002) and Maurstad et al. (2013), as the 
journals were not within the Medline or CAB Abstracts databases. A more detailed systematic review would require inclusion of other databases that may be more inclusive of other social science journals and studies, such as the International Bibliography of the Social Sciences. This scoping review has demonstrated the diversity of the publications in this area and therefore the challenges in defining databases and search strategies for an area that is currently ill defined and multi-disciplinary in nature. A systematic review investigating human-animal relationships, bonds and interactions performed by Hosey and Melfi (2014) identified 116 publications involving companion animals (dogs, cats and equids), of which 22 involved the human-animal relationship. This review did not state how many of these publications involved equids exclusively, however it suggests that 27 publications identified by this current review represents a reasonable body of the current evidence. There were however methodological differences, including the databases searched (Proquest and Google Scholar) and the lack of defined inclusion and exclusion criteria in the study by Hosey and Melfi (2014).

Of the publications reviewed in the current study, only one involved the dyadic relationship of human and horse, with the majority focusing only on one perspective (horse or human). The lack of exploration of the two-way interaction between humans and animals was also identified by Dwyer et al. (2006), subsequently leading to the development of the Monash Dog Owner Relationship Scale (Dwyer et al. 2006). Further research into the two-way relationship between horses and humans may be beneficial to understand how best to match horses with owners or riders, and to prevent incompatibilities that may become detrimental to the horse or human.

A diverse range of publication aims, objectives and methodologies were identified in this review, and there was significant diversity in the research areas and topics. Some major gaps in the research and lack of evidence for a number of areas were identified, and these were used to identify areas which should be considered for future research:

1. Development of a reliable and repeatable tool for categorising horse owners' motivations and reasons for being involved with horses.

2. Development of a reliable and repeatable system for categorising the different roles and activities that horses are used for.

3. Development of a tool for defining the different types of relationships people form with horses and other equids.

4. Identification of the horse factors and the owner factors that influence the horse-human relationship, and how these interact and affect owner decision making.

It can be concluded that the research surrounding the relationships between horse and human is extremely diverse and heterogeneous, with a paucity of evidence in most areas. From this scoping review of the literature, key areas of current research evidence were identified and defined, but gaps within the research body exploring the nature and factors influencing the horse-human relationship were also documented. The main limitations were around the challenges in identifying suitable publications, and social science databases should be included in future reviews. This review highlights the need for further investigation (systematic reviews) into the main research areas defined by the review, but also the need for new studies to fill significant gaps within the research. Gaining an understanding of the relationships we have with animals is important to help us understand how and why health and welfare may be compromised by inadequate or inappropriate decision making. The horse-human relationship is clearly a key component of this but is lacking a significant evidence-base. Exploration into the relationships that horse owners have with their horses, and the influence this may have on their decisions was identified as an area with little published literature. 
The authors declare no conflicts of interest.

Funding: This work was funded by The Horse Trust as part of a MRes studentship for Harriet Clough.

\section{REFERENCES}

1. ACTON, A. 2014. Equine gatekeepers, animal narratives and foxhunting landscapes. Anthrozoos, 27, 81-94. DOI: https://doi.org/10.2752/175303714X13837396326459

2. ARKSEY, H. \& O'MALLEY, L. 2005. Scoping studies: towards a methodological framework. International Journal of Social Research Methodology, 8, 19-32. DOI:

https://doi.org/10.1080/1364557032000119616

3. BETA NATIONAL EQUINE SURVEY. 2019.

4. BROWN, S. E. 2007. Companion animals as selfobjects. Anthrozoos, 20, 329-343. DOI: http://dx.doi.org/10.2752/089279307X245654

5. BUTLER, D., VALENCHON, M., ANNAN, R. \& WHAY, H.R. 2019. Living the 'Best Life' or 'One Size Fits All'Stakeholder Perceptions of Racehorse Welfare. Animals, 9(4), 134. DOI:

http://dx.doi.org/10.3390/ani9040134

6. CHAMOVE, A. S., CRAWLEY-HARTRICK, O. J. \& STAFFORD, K. J. 2002. Horse reactions to human attitudes and behavior. Anthrozoös, 15, 323-331. DOI:

http://dx.doi.org/10.2752/089279302786992423

7. DALY, B. \& MORTON, L. L. 2006. An investigation of human-animal interactions and empathy as related to pet preference, ownership, attachment, and attitudes in children. Anthrozoos, 19, 113-127. DOI: http://dx.doi.org/10.2752/089279306785593801

8. DASHPER, K. 2014. Tools of the trade or part of the family? Horses in competitive equestrian sport. Society \& Animals, 22, 352-371. DOI: http://dx.doi.org/10.1163/15685306-12341343

9. DASHPER, K. 2017. Listening to horses: Developing attentive interspecies relationships through sport and leisure. Society \& Animals, 25, 207-224. DOI: https://doi.org/10.1163/15685306-12341426

10. DAVIS, D., MAURSTAD, A. \& COWLES, S. 2013. "Riding up forested mountain sides, in wide open spaces, and with walls": developing an ecology of horse-human relationships. Humanimalia: A Journal of Human/Animal Interface Studies, 4, 54-83.

11. DEARAUGO, J., MCLEAN, A., MCLAREN, S., CASPAR, G., MCLEAN, M. \& MCGREEVY, P. 2014. Training methodologies differ with the attachment of humans to horses. Journal of Veterinary Behavior: Clinical Applications and Research, 9, 235-241. DOI: http://dx.doi.org/10.1016/i.jveb.2014.05.001

12. DUBOIS, C., NAKONECHNY, L., DERISOUD, E. \& MERKIES, K. 2018. Examining Canadian equine industry participants' perceptions of horses and their welfare. Animals (Basel), 8(11), E201. DOI: http://dx.doi.org/10.3390/ani8110201

13. DWYER, F., BENNETT, P.C. \& COLEMAN, G.J. 2006. Development of the Monash dog owner relationship scale (MDORS). Anthrozoös, 19, 243-256. DOI: http://dx.doi.org/10.2752/089279306785415592

14. ENDENBURG, N., KIRPENSTEIJN, J. \& SANDERS, N. 1999. Equine euthanasia: The veterinarian's role in providing owner support. Anthrozoös, 12, 138-141. DOI:

http://dx.doi.org/10.2752/089279399787000219

15. GRAF, P., BORSTEL, U K.V. \& GAULY, M. 2013. Importance of personality traits in horses to breeders and riders. Journal of Veterinary Behavior: Clinical Applications and Research, 8, 316-325. DOI: http://dx.doi.org/10.1016/j.jveb.2013.05.006

16. GRANT, M.J. \& BOOTH, A. 2009. A typology of reviews: an analysis of 14 review types and associated methodologies. Health Information \& Libraries Journal, 26, 91-108. DOI: http://dx.doi.org/10.1111/j.1471-1842.2009.00848.x

17. GRINDLAY, D.J., BRENNAN, M.L. \& DEAN, R.S. 2012. Searching the veterinary literature: a comparison of the coverage of veterinary journals by nine bibliographic databases. Journal of Veterinary Medical 
Education, 39, 404-412. DOI: http://dx.doi.org/10.3138/ivme.1111.109R

18. HAUSBERGER, M. \& MULLER, C. 2002. A brief note on some possible factors involved in the reactions of horses to humans. Applied Animal Behaviour Science, 76, 339-344. DOI:

http://dx.doi.org/10.1016/S0168-1591(02)00016-3

19. HAUSBERGER, M., ROCHE, H., HENRY, S. \& VISSER, E.K. 2008. A review of the human-horse relationship. Applied Animal Behaviour Science, 109, 1-24. DOI:

https://doi.org/10.1016/i.applanim.2007.04.015

20. HINDE, R. 1979. Towards understanding relationships. Academic Press, London.

21. HOCKENHULL, J. \& CREIGHTON, E. 2012a. The strengths of statistical techniques in identifying patterns underlying apparently random behavioral problems in horses. Journal of Veterinary Behavior: Clinical Applications and Research, 7, 305-310. DOI: http://dx.doi.org/10.1016/i.jveb.2011.11.001

22. HOCKENHULL, J. \& CREIGHTON, E. 2012b. A brief note on the information-seeking behavior of UK leisure horse owners. Journal of Veterinary Behavior: Clinical Applications and Research, 8, 106-110. DOI: http://dx.doi.org/10.1016/j.jveb.2012.04.002

23. HOSEY, G. \& MELFI, V. 2014. Human-animal interactions, relationships and bonds: a review and analysis of the literature. International Journal of Comparative Psychology, 27.

24. IJICHI, C., GRIFFIN, K., SQUIBB, K. \& FAVIER, R. 2018. Stranger danger? An investigation into the influence of human-horse bond on stress and behaviour. Applied Animal Behaviour Science. 206, 5963. DOI: http://dx.doi.org/10.1016/j.applanim.2018.05.034

25. IKINGER, C., SPILLER, A. \& KAYSER, M. 2016. Factors influencing the attitude of equestrians towards sport horse welfare. Animal Welfare, 25, 411-422. DOI: http://dx.doi.org/10.7120/09627286.25.4.411

26. JORGENSEN, G.H.M., FREMSTAD, K E., MEJDELL, C.M. \& BOE, K.E. 2011. Separating a horse from the social group for riding or training purposes: a descriptive study of human-horse interactions. Animal Welfare, 20, 271-279.

27. KEELING, L.J., JONARE, L. \& LANNEBORN, L. 2009. Investigating horse-human interactions: the effect of a nervous human. Veterinary Journal, 181, 70-71. DOI: http://dx.doi.org/10.1016/i.tvil.2009.03.013

28. LEE DAVIS, D., MAURSTAD, A. \& DEAN, S. 2015. My Horse Is My Therapist: The Medicalization of Pleasure among Women Equestrians. Medical Anthropology Quarterly, 29, 298-315. DOI: http://dx.doi.org/10.1111/maq.12162

29. MATHERS, M., CANTERFORD, L., OLDS, T., WATERS, E. \& WAKE, M. 2010. Pet ownership and adolescent health: cross-sectional population study. Journal of Paediatrics \& Child Health, 46, 72935. DOI: http://dx.doi.org/10.1111/j.1440-1754.2010.01830.x

30. MAURSTAD, A., DAVIS, D. \& COWLES, S. 2013. Co-being and intra-action in horse-human relationships: a multi-species ethnography of be (com) ing human and be (com) ing horse. Social Anthropology, 21, 322-335. DOI: https://doi.org/10.1111/1469-8676.12029

31. MCGOWAN, T.W., PHILLIPS, C.J.C., HODGSON, D.R., PERKINS, N. \& MCGOWAN, C M. 2012. Euthanasia in aged horses: relationship between the owner's personality and their opinions on, and experience of, euthanasia of horses. Anthrozoos, 25, 261-275. DOI:

http://dx.doi.org/10.2752/175303712X13403555186091

32. MOHER, D., LIBERATI, A., TETZLAFF, J., ALTMAN, D.G. \& The PRISMA Group. 2009. Preferred Reporting Items for Systematic Reviews and Meta-Analyses: The PRISMA Statement. PLoS Med 6(7). DOI: http://dx.doi.org/10.1371/journal.pmed.1000097

33. MUELLER, M K., SWEEN, C., FRANK, N. \& PARADIS, M.R. 2018. Survey of human-horse relationships and veterinary care for geriatric horses. Journal of the American Veterinary Medical Association. 253 (3), 337-345. DOI: http://dx.doi.org/10.2460/javma.253.3.337

34. NAKAMURA, K., TAKIMOTO-INOSE, A. \& HASEGAWA, T. 2018. Cross-modal perception of human emotion in domestic horses (Equus caballus). Scientific Reports. 8(1), 8660. DOI: http://dx.doi.org/10.1038/s41598-018-26892-6

35. SCANTLEBURY, C.E., PERKINS, E., PINCHBECK, G.L., ARCHER, D.C. \& CHRISTLEY, R.M. 2014. Could it be colic? Horse-owner decision making and practices in response to equine colic. BMC Veterinary Research, 10. DOI: http://dx.doi.org/10.1186/1746-6148-10-S1-S1 
36. SIGHIERI, C., TEDESCHI, D., ANDREIS, C.D., PETRI, L. \& BARAGLI, P. 2003. Behaviour patterns of horses can be used to establish a dominant-subordinate relationship between man and horse. Animal Welfare, 12, 705-708.

37. SPRINGER, S., JENNER, F., TICHY, A. \& GRIMM, H. 2019. Austrian Veterinarians' Attitudes to Euthanasia in Equine Practice. Animals (Basel) 9(2), 44. DOI: http://dx.doi.org/10.3390/ani9020044

38. THOMPSON, K. \& NESCI, C. 2016. Over-riding concerns: developing safe relations in the high-risk interspecies sport of eventing. International Review for the Sociology of Sport, 51, 97-113. DOI: http://dx.doi.org/10.1177/1012690213513266

39. TRICCO, A.C., LILLIE, E., ZARIN, W., O'BRIEN, K.K., COLQUHOUN, H., LEVAC, D., MOHER, D., PETERS, M.D.J., HORSLEY, T., WEEKS, L., HEMPEL, S., AKL, E.A., CHANG, C., MCGOWAN, J., STEWART, L., HARTLING, L., ALDCROFT, A., WILSON, M.G., GARRITTY, C., LEWIN, S., GODFREY, C.M., MACDONALD, M.T., LANGLOIS, E.V., SOARES-WEISER, K., MORIARTY, J., CLIFFORD, T., TUNÇALP, Ö. \& STRAUS, S.E. 2018. PRISMA extension for scoping reviews (PRISMA-ScR): checklist and explanation. Annals of internal medicine, 169(7), 467-473. DOI: http://dx.doi.org/10.7326/M18-0850

40. VIKSTEN, S.M., VISSER, E. K., NYMAN, S. \& BLOKHUIS, H.J. 2017. Developing a horse welfare assessment protocol. Animal Welfare, 26, 59-65. DOI: http://dx.doi.org/10.7120/09627286.26.1.059

41. WORLD HORSE WELFARE. 2019. International work. 


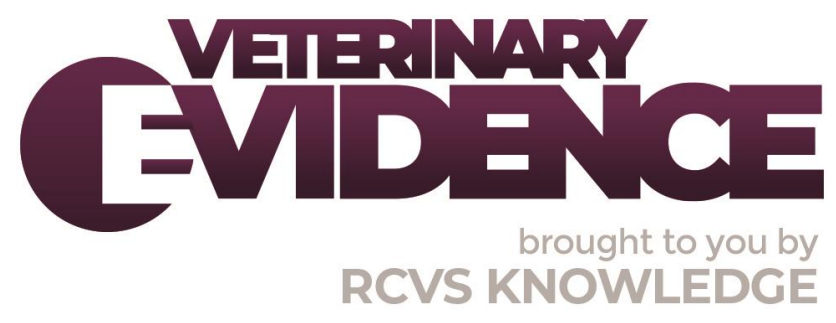

\section{Intellectual Property Rights}

Authors of Knowledge Summaries submitted to RCVS Knowledge for publication will retain copyright in their work, and will be required to grant RCVS Knowledge a non-exclusive license of the rights of copyright in the materials including but not limited to the right to publish, re-

publish, transmit, sell, distribute and otherwise use the materials in all languages and all media throughout the world, and to license or permit others to do so.

\section{Disclaimer}

Any opinions expressed in articles and other publication types published in Veterinary Evidence are the author's own and do not necessarily reflect the view of the RCVS Knowledge. Veterinary Evidence is a resource to help inform, and the content herein should not override the responsibility of the practitioner. Practitioners should also consider factors such as individual clinical expertise and judgement along with patient's circumstances and owners' values. Authors are responsible for the accuracy of the content. While the Editor and Publisher believe that all content herein are in accord with current recommendations and practice at the time of publication, they accept no legal responsibility for any errors or omissions, and make no warranty, express or implied, with respect to material contained within.

For further information please refer to our Terms of Use.

RCVS Knowledge is the independent charity associated with the Royal College of Veterinary Surgeons (RCVS). Our ambition is to become a global intermediary for evidence based veterinary knowledge by providing access to information that is of immediate value to practicing veterinary professionals and directly contributes to evidence based clinical decision-making.

https://www.veterinaryevidence.org/

RCVS Knowledge is a registered Charity No. 230886.

Registered as a Company limited by guarantee in England and Wales No. 598443.

Registered Office: Belgravia House, 62-64 Horseferry Road, London SW1P 2AF

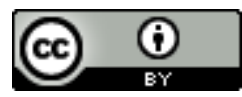

This work is licensed under a Creative Commons Attribution 4.0 International License. 